\title{
Bovine Leukemia Virus Presence in Breast Tissue of Argentinian Females and Its Association With Cell Proliferation and Prognostic Markers
}

\author{
Pamela Anahí Lendez ${ }^{1}$, Lucía Martínez Cuesta ${ }^{1}$, María Victoria Nieto \\ Farias $^{1}$, Hua Min Shen ${ }^{2}$, Guillermina Laura Dolcini' ${ }^{1}$, Gertrude Case \\ Buehring $^{2}$, Maria Carolina Ceriani ${ }^{1,}$ \\ ${ }^{1}$ Virology Laboratory, Faculty of Veterinary Sciences, UNCPBA-CONICET \\ (CIVETAN)-CICPBA, Tandil, Argentina \\ ${ }^{2}$ School of Public Health, University of California, Berkeley, California, USA \\ *Corresponding author: Maria Carolina Ceriani, Virology Laboratory, Faculty \\ of Veterinary Sciences, UNCPBA-CONICET (CIVETAN)-CICPBA. University \\ Campus, Paraje Arroyo Seco s/n, 7000 Tandil, Argentina. Tel.: + 542494385850; \\ Fax:+542494385850;E-mail: cceriani@vet.unicen.edu.ar
}

DOI: 10.30699 /acadpub.mci.4.16

Submitted: 1 September 2018

Revised: 15 September 2018

Accepted: 22 September 2018

e-Published: 1 October 2018

\section{Keywords:}

Leukemia Virus, Bovine Human Breast Cancer Direct In Situ PCR Cell Proliferation Prognosis
Abstract

Introduction: Bovine leukemia virus (BLV) causes enzootic bovine leukemia, and is closely related to human T-lymphotropic virus type 1 . It expresses microRNAs of unknown function and codes Tax, the protein that mediates malignant transformation. BLV is capable of infecting B- and T-lymphocytes, endothelial cells, and mammary epithelial cells of cattle. Several studies demonstrated the presence of BLV DNA in human tissue, and it is significantly associated with breast cancer in case-control studies using in situ Polymerase Chain Reaction (PCR), a highly sensitive and specific technique. The current study was the first report of BLV DNA detection by in situ PCR in tissue from Argentinian females with a diagnosis of breast cancer.

Methods: In situ PCR was done to detect BLV DNA in 85 human FFPE breast cancer tissue samples. The association of BLV DNA and expression of Ki67 and Her-2 was assessed.

Results: BLV DNA presence could be determined in $22.6 \%$ of the analyzed samples, and its presence was associated with an increase of the expression and prognostic markers Ki67 $(\mathrm{P}=0.009)$ and HER-2 $(\mathrm{P}=0.044)$ determined by conventional immunohistochemistry. No statistical significance was observed between the presence or absence of hormonal receptors and the presence of BLV DNA.

Conclusions: The obtained results support the idea that BLV might play a role in malignant tissue transformation.

(C) 2018. Multidisciplinary Cancer Investigation

\section{INTRODUCTION}

Breast cancer is the most common cancer in females worldwide, and the second most common cancer overall. It is also a leading cause of cancer death in the developing countries [1], partly since the shift toward lifestyles typical of industrialized countries leads to a rising burden of cancers associated with dietary and hormonal risk factors, and partly clinical advances to combat breast cancer are not always available to females living in such regions. The IARC (International Agency for Research on 
Cancer, WHO) estimations for 2012 rank Argentina among the countries with medium-high incidence of cancer with an estimated 17,000 breast cancer cases newly diagnosed each year. Breast cancers comprise $18 \%$ of all the cancer cases and $36 \%$ of cancers in the females of Argentina [2]. In 2016, all medical associations in Argentina involved in the diagnosis and treatment of breast cancer, including the National Academy of Medicine, followed the model of ASCO/CAP in the US to develop guidelines and a mandate for pathologists to test breast cancer specimens for estrogen receptor (ER), progesterone receptor (PR), growth factor receptor HER-2, and cell division indicator Ki67, for all cases of in situ breast carcinoma, invasive primary breast cancer, and metastatic breast cancer received in their laboratories. These determinations can be done by either immunohistochemistry or fluorescent in situ hybridization (FISH), if laboratories are appropriately certified. Testing for this panel of biomarkers is routine in most of the developed countries as a first step towards individualized patient therapy.

Identifying what contributes to the initiation and early development of breast cancer is important to design adequate strategies to prevent and treat this disease. Some risk factors are identified, e.g. family history, long term exposure to endogenous estrogens, longer time between menarche and menopause, low parity, exogenous hormones, obesity, and sedentary lifestyle [2]. However, these risk factors are not likely to initiate the events that lead to malignant transformation of normal breast epithelial cells. It is estimated that ionizing radiation initiates $<5 \%$ of all breast cancers. Viruses are estimated to cause $15 \%$ $20 \%$ of all human cancers. Viruses most frequently investigated in connection with human breast cancer are human papilloma virus (HPV), Epstein Barr virus (EBV), and murine mammary virus (MMTV) [3-5]; recently, bovine leukemia virus (BLV) is added to the virus candidates $[6,7]$. The way BLV could enter the cells and infect them remains unknown. Recently a paper was published, where it was shown, in silico and in vitro, the interaction of bovine AP3D1, the putative cell surface receptor, and the viral 51$\mathrm{kDa}$ glycoprotein gp51. This model suggested the receptor-ligand interactions, which could occur in BLV infection, and lead to viral binding and fusion regarding viral entry. The PSI-BLAST analysis of boAP3D1 predicted $88 \%$ identity with human protein for AP3D [8]. BLV is a deltaretrovirus that infects cattle, most of which remain asymptomatic, constituting a continuous source of infection for the rest of the herd. Leukemia/lymphoma, a fatal disease, develops in only about $5 \%$ of infected animals, and it always ends with the death of the animal. The prevalence of infected cows in Argentina is more than $40 \%$ in dairy cows and $10 \%$ to $30 \%$ in beef cattle as informed by the National Agriculture Health Service (SENASA) in 2016, and the percentage of infected herds, harboring one or more infected animals, was $84 \%$ in 2001 , the latest documented record available in Argentina [9]. BLV follows the typical retroviral genomic organization: LTR (long-terminal repeat, promoter region); gag (group-specific antigen, capsid region); pol (polymerase, reverse transcription region); and env (envelope). However, deltaretroviruses have an additional region, tax (trans-activating region of the $\mathrm{X}$ gene), which has regulatory functions and is oncogenic to host cells. This protein causes malignant transformation by a pathway different from many other retroviruses. It inhibits DNA repair and trans-activating disruption of cellular growth control mechanisms, instead of inducing tumorigenesis by insertional mutagenesis or integration [10].

In Argentina, the average meat consumption in 2016 was $60 \mathrm{~kg} /$ inhabitant/year, as informed by the IPCVA (Instituto de Promoción de la carne vacuna Argentina) a public non-state entity devoted to improving and consolidating Argentine meat products. The milk consumption is around 210 liter/inhabitant/year. This includes milk and all its derivatives, as informed by the FAO (Food and Agriculture Organization of the United Nations), which locates Argentina among the countries with the highest consumption of milk in the world, together with the US, Australia, and Europe. This consumption is distributed in $78 \%$ as white milk, $11 \%$ derivatives as yoghurts and flavored beverages, and a very little consumption of nursing milks. In the current study, samples were selected from a reduced population, probably not exactly representative of the average inhabitant of the country. According to the location of the city, and that all the biopsies were taken in private clinics, it can be assumed that patients belonged to middlehigh income group. It implies that consumption of meat, milk, and its derivatives could be higher than the average of the Argentinian population. These are very important data if the prevalence of BLV 
in the herds is considered [9]. There are very few studies on the prevalence of BLV in beef cattle, but it is worth saying, as mentioned before, that milk consumption in Argentina is considered elevated. The prevalence of BLV in dairy cows in Argentina is around $80 \%$. The mechanism by which BLV could enter the human body is still unknown, but there are some hypothesis $[6,7]$.

Although the zoonotic potential of BLV is not yet proven, there are several lines of evidence that suggest its plausibility. In bovines, there is reported evidence of BLV transmission to calves through milk and blood [11]. In humans, presence of serum antibodies against BLV [12], and retrotranscribed DNA in breast tissue sections [6, 13] and lung tumors [14] are reported. These findings, plus the close relationship of BLV with HTLV-1 and-2, led researchers to hypothesize that BLV could behave as a zoonotic agent, and its association with human breast cancer is postulated [7]. Generally, worldwide trends show that in the developing countries going through rapid societal and economic changes and the shift towards lifestyles typical of industrialized countries lead to a rising burden of cancers associated with reproductive, dietary, and hormonal risk factors. Since there is evidence regarding the presence of BLV proteins and genomic fragments in human breast tissue, a lot of studies should be performed to reassure the issue that BLV can effectively be associated with human breast cancer.

The current study aimed at investigating, for the first time, the presence of BLV DNA in breast cancer tissue of females in Argentina; and, in case of positivity, determining an association of BLV DNA presence in breast malignant tissue with the most common prognostic biomarkers used to predict tumor hormone responsiveness and proliferation aggressiveness; this would help to elucidate if BLV might initiate or help to develop cancer in the human breast.

\section{METHODS}

\section{Sample Collection}

Archived formalin-fixed paraffin-embedded (FFPE) human breast cancer samples $(\mathrm{n}=85)$ were randomly selected disregard of age or diagnosis from the biorepository of a private laboratory, from a city with 140,000 inhabitants, located in the Central area of Argentina. The patient's age range fluctuated from 29 to 84 years, with a high percentage of the patients over 50 years old $(87 \%)$, five patients were
29 to $45(5 \%)$, and six 45 to 50 years old $(6 \%)$. All samples were primary tumors of the breast collected from 2012 to 2015 . Tissue sections were cut $5-\mu$ thick, mounted on super adherent glass slides (Fisher Brand, Super frost Plus, Fisher Scientific, USA), and sent to the collaborating research laboratory at the University of California, Berkeley. Extreme care was taken to insure the area of invasive cancer was included in specimens analyzed in the current study. Negative tissue was obtained from patients subjected to reduction mammaplasty (4/4 less than 35 years old).

\section{In Situ Polymerase Chain Reaction (PCR) Amplification}

In situ PCR methodology, with slight modifications, was employed to amplify a 114-bp DNA segment from the tax gene region, as indicated by Buehring et al. [7]. Reactions were performed on two adjacent sections cut from each tissue and mounted on the same slide. Samples were permeabilized at room temperature (RT) by digestion with $2 \mathrm{mg} / \mathrm{mL}$ pepsin in $0.1 \mathrm{~N} \mathrm{HCl}$ (40-80 minutes); pepsin inactivation solution (100 mM Tris-HCl, $100 \mathrm{mM} \mathrm{NaCl}, \mathrm{pH}$ 7.4) was applied for one minute, followed by a rinse with Dulbecco's phosphate buffered saline (DPBS) and 5 minute to 48 hours in absolute ethanol. Each of the two sections from a single patient was surrounded by a separate $15 \times 15 \mathrm{~mm}$ frame seal chamber (BioRad, Richmond, California, USA); $65 \mu \mathrm{L}$ of PCR mix was then placed into each chamber, and the accompanying plastic cover was sealed over each frame. The PCR mixture was $4 \mathrm{mM} \mathrm{MgCl} 2,0.4$ $\mathrm{mM}$ dNTPs, $0.06 \%$ bovine serum albumin (BSA), $0.053 \mathrm{U} / \mu \mathrm{L}$ AmpliTaq Gold DNA Polymerase (Applied Biosystems, California, USA) and $1 \mu \mathrm{M}$ of each primer. The location of the used tax primers is shown below in base pair numbering according to GenBank accession \#EF600696.

Forward (bp 7310-7329):

ATGTCACCATCGATGCCTGG

Reverse (bp 7423-7404):

\section{CATCGGCGGTCCAGTTGATA}

Slides were placed into an in situ PCR machine (Hybaid Omnislide Thermocycler, Thermo Scientific, USA) for amplification. The employed cycling parameters were: one cycle of $93^{\circ} \mathrm{C}$ for 10 minutes, $57^{\circ} \mathrm{C}$ for one minute, 33 seconds, then 30 cycles of $92^{\circ} \mathrm{C}$ for 30 seconds, $57^{\circ} \mathrm{C}$ for one minute, 30 seconds, and $69^{\circ} \mathrm{C}$ for two minutes, followed by a final extension at $69^{\circ} \mathrm{C}$ for 10 minutes. 


\section{Probe Labelling}

Probe labeling for in situ hybridization (ISH) was performed with the PCR Dig Probe Synthesis Kit (Roche) according to the manufacturer's instructions, including recommended adjustments for short probes $(<1 \mathrm{~kb})$ with high $\mathrm{GC}$ content. Template DNA was from fetal lamb kidney (FLK) cells stably infected with BLV. The reaction mixture was: $5 \mu \mathrm{L}$ of $10 \mathrm{X}$ provided buffer containing $\mathrm{MgCl}_{2}$ and an additional $1 \mu \mathrm{L}$ of $25 \mathrm{mM} \mathrm{MgCl}_{2}$ (to optimize for the specific primers used in these experiments), $2.5 \mu \mathrm{L}$ digoxigenin probe synthesis mix, $2.5 \mu \mathrm{L}$ stock dNTPs, $0.5 \mu \mathrm{M}$ of each primer, $0.75 \mu \mathrm{L}$ kit enzyme mix, $200 \mathrm{ng}$ template DNA, and PCR grade water added up to total volume of $50 \mu \mathrm{L}$. The cycling parameters were: one cycle of $95^{\circ} \mathrm{C}$ for two minutes, then 33 cycles of $95^{\circ} \mathrm{C}$ for 30 seconds, $56^{\circ} \mathrm{C}$ for 30 seconds, and $72^{\circ} \mathrm{C}$ for 45 seconds, followed by a final extension at $72^{\circ} \mathrm{C}$ for seven minutes. PCR was performed in a conventional thermocycler. The amplified fragments were visualized in $2 \%$ agarose gel with ethidium bromide before use.

\section{In Situ Hybridization}

Hybridization mixture was prepared at 1:3 ratio of labeled probe: hybridization buffer (Enzo Life Sciences cat\# ENZ-33808). Slides were rinsed once in DPBS, once in $2 \mathrm{X} \mathrm{SSC}$ (saline sodium citrate) at RT for five minutes and once again with $2 \mathrm{X}$ SSC at $37^{\circ} \mathrm{C}$ for five minutes. Sections were fixed 10 minutes with $10 \%$ buffered formalin, washed with PBS, and dehydrated with absolute ethanol for five minutes; $20 \mu \mathrm{L}$ of the hybridization mix was added to one of the two sections on each slide, and the other tissue section on the same slide received hybridization buffer without the probe as a control for false positive reactions due to endogenous peroxidase, melanin inherent in the tissue, or DNA repair by the Taq polymerase. Each section was covered with a separate cover slip (22 mm diameter, Corning ${ }^{\circledR}$ glass cover slip) and placed into the in situ PCR machine. Denaturation of the DNA was performed at $95^{\circ} \mathrm{C}$ for 10 minutes, and hybridization at $37^{\circ} \mathrm{C}$ in a moist box overnight.

\section{Detection of the Labeled Probe}

Tissue sections were gently rinsed with DPBS. Endogenous tissue peroxidase was quenched for 30 minutes with $3 \% \mathrm{H} 2 \mathrm{O} 2$, washed with DPBS and soaked with $1 \%$ bovine serum albumin (BSA) in
2X SSC for 15 minutes at $37^{\circ} \mathrm{C}$. The reaction was developed by adding 1:100 anti-dig-POD antibody (polyclonal anti-digoxigenin antibodies, Roche Diagnostics) to each section, and visualizing the final outcome signal (brown color) with diaminobenzidine (DAB, Sigma Cat \# 32750).

\section{Immunohistochemical Determination}

Immunohistochemistry was performed according to the manufacturer's recommendation (Vector Lab, Burlingame, Ca. USA) with slight modifications adapted to the working conditions of the current study. Briefly, FFPE sections cut 5 - $\mu \mathrm{m}$ thick, mounted on glass super adherent slides, and were dried overnight at $37^{\circ} \mathrm{C}$. Prior to antibody staining, the tissue sections were pre-treated to unmask binding epitopes. Briefly, after quenching endogenous peroxide activity (3\% hydrogen peroxide in methanol, 30 minutes), slides were immersed in $200 \mathrm{~mL}$ of $10 \mathrm{mM}$ citrate buffer (pH 6.0) in a domestic microwave for five minutes on power setting of $1000 \mathrm{~W}$, followed by two cycles, five minutes each, on power of $500 \mathrm{~W}$. Slides were then held for 60 minutes in citrate buffer at RT before washing thoroughly in tap water and rinsed three times in PBS. All reactions were performed at RT. Slides were incubated with a ready-to-use (RTU) mouse antiER monoclonal primary antibody (Clone 6F11), RTU mouse anti-PgR monoclonal primary antibody (Clone 312), RTU mouse anti-HER-2 monoclonal primary antibody (clone CB11), and RTU mouse anti-Ki67 monoclonal primary antibody (Clone MM1) for 18 hours. All the monoclonal antibodies were purchased from Leica Biosystems, New Castle, UK. Tissue sections were then washed three times with PBS, and RTU biotinylated goat antibody secondary antibody to mouse/rabbit immunoglobulin (Universal Quick Kit, Vector PK 7200) was applied for one hour. After an additional three washes with PBS, RTU antibody streptavidin-biotin/horse radish peroxidase (HRP) complex (Universal Quick Kit, Vector PK 7800) was added. After rinsing three times with PBS, the final color was visualized by reacting with DAB (SK-4100, Vector Lab, Burlingame, Ca. USA) for 10 minutes in the dark. The slides were washed well in tap water and counterstained with Harris's hematoxylin for 20 seconds to one minute; then dehydrated, cleared, mounted, and observed with a light microscope. Ki67 index was classified as low $(+)$ when less than $30 \%$ of the malignant cells were stained and as moderate/high $(++$ or +++$)$ if more than $30 \%$ of the cells were stained. 


\section{Statistical Analysis}

The association between the presence of BLV, and the hormonal receptors, HER-2, and the proliferative index marker Ki67 in the tissue was estimated with the Chi-square test $(\mathrm{P}<0.05)$. A free version of InfoStat (Universidad Nacional de Cordoba, Argentina) was employed.

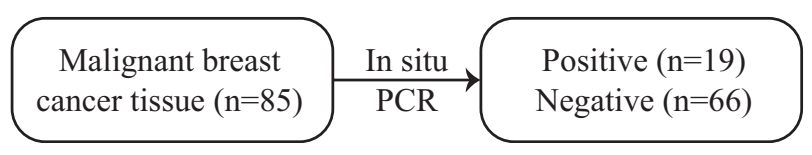

\section{RESULTS}

Nineteen of $85(22.36 \%)$ malignant breast cancer samples were positive for the targeted conserved region of BLV tax gene (Figure 1). Four nonmalignant tissue samples were analyzed. Biopsies were obtained from reduction mammaplasties. Only in one case BLV DNA was detected.

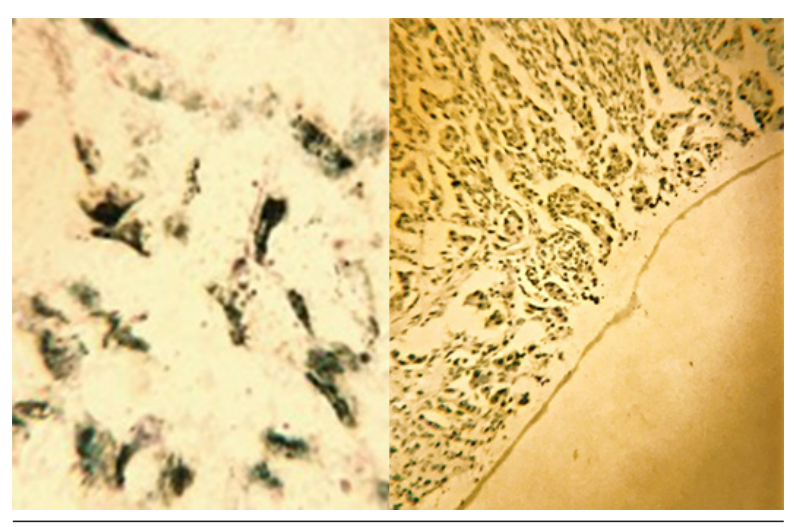

Figure 1: In Situ PCR Hybridization

Left panel: slide (1000X), stained with methylene blue. Dark spots are visualized in cell cytoplasm when reaction was positive for BLV Tax determination. Right panel: 10X magnification.

The presence of hormonal receptors for estrogen (ER) and progesterone (PR) tested by immunohistochemistry are indicated in Table 1. No statistical significance was observed between the presence or absence of hormonal receptors and presence of BLV DNA. The same methodology was applied to determine the expression of the proliferative marker Ki67, which is associated with a poor prognosis, but has a better response to chemotherapy. Samples were classified as moderate to high proliferation index (++, from $15 \%$ to $60 \%$ positive cells or +++ , more than $60 \%$ positively stained cells), or low proliferation index $(+$, less than $15 \%$ of positive cells), (Figure 2). A statistically significant association was observed between the proliferative rate and the presence of BLV tax DNA ( $\mathrm{P}=0.009)$. A high/moderate proliferative index was observed in $13 / 18(72.22 \%)$ positive samples and in only 25/63 (39.68\%) of negative samples (Table 1). For the oncogen HER-2, there was significant association between the positivity for the marker and the presence of $\operatorname{BLV}(\mathrm{P}=0.044)$ (Figure 2).

Table 1: Immunohistochemistry Analysis for Hormone Receptors, Ki67 and HER-2 in BLV-Positive Versus BLV-Negative Tissue Samples

\begin{tabular}{|c|c|c|c|}
\hline & $\begin{array}{c}\text { BLV } \\
\text { Positive }\end{array}$ & $\begin{array}{c}\text { BLV } \\
\text { Negative }\end{array}$ & P Value \\
\hline $\begin{array}{l}\text { Estrogen Receptors } \\
(\mathrm{n}=\mathbf{8 3})^{\mathrm{a}}\end{array}$ & & & 0.178 \\
\hline Positive & 12 & 51 & \\
\hline Negative & 7 & 13 & \\
\hline $\begin{array}{l}\text { Progesterone } \\
\text { Receptors }(n=84)^{a}\end{array}$ & & & 0.249 \\
\hline Positive & 10 & 42 & \\
\hline Negative & 9 & 23 & \\
\hline Ki $67(n=81)^{a}$ & & & 0.009 \\
\hline Positive & 13 & 25 & \\
\hline Negative & 5 & 38 & \\
\hline HER- $2(n=82)^{a}$ & & & 0.044 \\
\hline Positive & 5 & 5 & \\
\hline Negative & 15 & 57 & \\
\hline
\end{tabular}

No significant association was observed between BLV status and either of the hormonal receptors determination. Presence of BLV was significantly associated with both high proliferation index (Ki67) $(\mathrm{P}=0.014)$ and the detection of oncogene HER-2 $(\mathrm{P}=0.042)$.

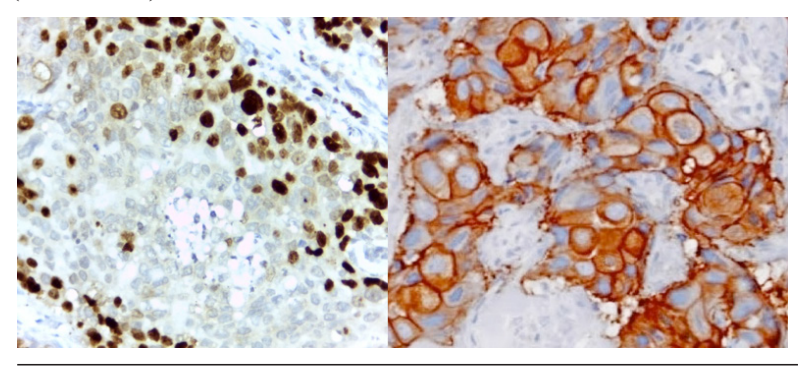

Figure 2: Immunohistochemistry for Prognostic Markers

Left panel: Ki67 determination stained with DAB, positive cells are brown (40X). Right panel: HER-2 determination stained with DAB. Brownish reaction is observed in the cytoplasmic side of plasmatic membrane (400X).

\section{DISCUSSION}

BLV is a deltaretrovirus which causes neoplastic 
disease of lymphoid tissue in cattle. The main target cells are B-lymphocytes, but it also naturally infects T-cells [15], endothelial cells [11], and mammary epithelial cells [16]. Most infected animals remain asymptomatic, but approximately 30\% develop a benign expansion of B-lymphocytes (persistent lymphocytosis) that persists for the entire life of the animal [17]. Less than 5\% of infected animals develop malignant B-cell lymphoma, even after a long latency period. These animals are usually culled from the herds and their products are not marketed. Transmission through the herd is due to transfer of infected lymphocytes, rather than extracellular viral particles [17]. In fact, BLV and its close relative human T-cell leukemia virus can be transmitted only by cell-cell contact through cytoplasmic bridges [18]. Infected cells can enter through the injured skin, alimentary, reproductive, or respiratory tract, frequently as a result of iatrogenic procedures [19]. A dam can infect the nursing calf through colostrum or milk in which the whole infected cells are plentiful [11].

Prevalence of BLV infection is much higher in dairy cattle than in beef cattle [20,21], possibly due to differences in herd management, breed differences in genetic susceptibility to BLV [22], and/or the fact that BLV is hormone responsive and is stimulated to replicate by corticosteroids and progesterone [23, 24] elevated during the constant pregnancy and lactation of dairy cows. High levels of BLV replication in dairy cows would stimulate higher antibody levels, more likely detected by the screening test for BLV. BLV has the promoter region (3' and 5' long terminal repeat [LTR]) and the coding genes: gag, coding for capsid protein, env, coding for the envelope protein, and pol for the reverse transcriptase (RNA dependent DNA polymerase) enzyme [10]. Unlike other families of oncogenic retroviruses, (alpha, beta, and gamma Retroviridae), it is not mandatory for deltaretroviridae to integrate into host cell DNA in order to initiate malignant transformation [25]. If they do integrate, there is no preferential integration upstream of a cellular oncogene [26]. BLV and the closely related HTLV 1 and 2 viruses synthesize an additional protein called Tax, not observed in other retroviral families. In addition to transactivating regulatory functions, Tax also mediates malignant transformation. While the mechanism of Tax oncogenicity is not fully understood, it disrupts lymphoid cell growth control [27] and inhibits DNA repair [28], which could result in accumulation of cellular genetic defects, possibly leading to leukemia [27]. Other areas of the BLV genome transcribing microRNAs and other RNAs that regulate microRNAs, are recently associated with maintaining the transformed state of BLV-infected cells $[29,30]$.

Retrotranscribed BLV DNA is detected in human breast tissue by standard solution PCR [13] and in situ PCR [6]. BLV structural proteins gp51 and p24 are also detected in human breast tissue [31]. Robinson et al., [14] detected BLV DNA in human lung carcinomas using a microbial detection microarray with a reference data base including all published sequences of vertebrate viruses [32]. Building upon the evidence of human infection with BLV, Buehring et al., [7] conducted a case-control study on 214 US human subjects using in situ PCR technique to detect sequences in the tax region, which codes for the protein responsible for malignant transformation of cells. They found that $59 \%$ of the patients with a cancer diagnosis were positive for BLV DNA, compared with $29 \%$ of the subjects with no history of breast cancer. This difference was highly significant with a multiply-adjusted odds ratio of 3.1. Recently, a study conducted in Australia detected the presence of a BLV tax gene before and after breast cancer development. In this opportunity, both standard and in situ PCR techniques were employed to detect BLV DNA in the tissue samples. These results showed that viral DNA could be detected in this tissue many years before the onset of the disease. In 10 cases, it was possible to obtain enough DNA to sequence the viral LTR. The LTR sequences were compared with a reference sequence. After comparison, authors showed that in six samples the LTRs had a $100 \%$ homology with the reference sequence and four had at least one substitution [33]. Collectively, these previous studies supported the idea that humans can be infected with BLV and that it might be a risk factor to develop breast cancer.

In the current study, all samples obtained from malignant breast tissue were routinely tested for hormonal receptors (estrogen and progesterone), proliferation marker Ki67, and overexpression of oncogene HER-2. Approximately, 50\% of the BLV positive slides were also positive for hormonal receptors, but no association was observed between hormone receptor status and the presence of BLV DNA. In contrast, a significant association was 
observed between BLV DNA presence and a high/ moderate proliferative index. Ki67, the marker for proliferation, recognizes an antigen present on the nuclear membrane surface of mammalian cells that are actively dividing. It is undetectable in stationary cells, not dividing. Ki67 is routinely used as a prognosis and predictive marker to diagnose breast cancer, since its expression is an indicator of the index of growth of the analyzed tissue [34]. The merit of this manuscript, besides being the first study performed in Argentina, was the relationship between the typical prognosis factors routinely quantified in patients with breast cancer and the presence of BLV DNA. This initial result opens a new perspective and further supports the idea that BLV might have a role in the initiation of malignant transformation of human breast epithelium, which generally results in more rapid cellular proliferation. The current study results showed that BLV could be detected by in situ PCR in 22.36\% of the females that the malignant breast tissue specimens originated in them. In similar studies performed in other countries, BLV DNA was present in a higher percentage of malignant tested tissues $[6,13,33]$. This difference could be due to the fact that samples were not processed from the beginning by the same operator, or, instead, since the number of samples was not large enough. A case-control study could not be conducted to determine if BLV were more frequent in malignant tissue than in normal breast tissue, since the only specimens available were invasive ductal carcinomas, the most common cancer in females. It is not usual in Argentina to conduct breast surgery to remove noncancerous tissue. Also, the sample size was too small for definitive statistics and a conclusion that BLV could be associated with breast malignancy. It is highly important to confirm that BLV is related to human breast cancer, since there are several instances in which humans can be exposed. A study conducted in Colombia reported that genetic material corresponding to the viral gene gag was present in fresh milk and raw meat [35]. Seroprevalence of antibodies against BLV in herds from the most important dairy regions of Argentina is approximately $90 \%[36,37]$. Government has no policies to encourage the elimination of infected animals or their separation from BLV-negative animals within a herd. Such measures are implemented in the European Union, where this infection in cattle is almost eradicated [38, 39] and in Australia where it is considered eradicated [40]. Several attempts are made in order to design an efficient vaccine against BLV. A novel strategy based on the use of a liveattenuated BLV provirus is developed. It is being tested regarding production, storage, and delivery, as well as safety of the milk produced by vaccinated cows [41]. In a recent review, the authors suggest different approaches that could be conducted in order to end the controversy of whether BLV is certainly related to human breast cancer development [42].

\section{ACKNOWLEDGMENTS}

The authors are grateful to Lorena Tapia for its technical assistance and Dr. S. Gentile for allowing the access to his biorepository.

\section{CONFLICT OF INTERESTS}

The authors declared no conflict of interest.

\section{ETHICS APPROVAL AND FINANCIAL SUPPORT}

The study was ethically and financially supported by SECAT-Universidad Nacional del Centro de la Provincia de Buenos Aires (UNCPBA), CONICET (PUE-CIVETAN) and CONICET PIP 196/14.

\section{REFERENCES}

1. Ferlay J, Soerjomataram I, Dikshit R, Eser S, Mathers C, Rebelo M, et al. Cancer incidence and mortality worldwide: sources, methods and major patterns in GLOBOCAN 2012. Int J Cancer. 2015;136(5):E359-86. DOI: 10.1002/ijc.29210 PMID: 25220842

2. Viniegra M, Paolino M, Arrossi S. [Breast cancer in Argentina: organization, coverage and quality of prevention and control actions]: Pan American Health Organization; 2010.

3. Joshi D, Buehring GC. Are viruses associated with human breast cancer? Scrutinizing the molecular evidence. Breast Cancer Res Treat. 2012;135(1):1-15. DOI: 10.1007/ s10549-011-1921-4 PMID: 22274134

4. Salmons B, Gunzburg WH. Revisiting a role for a mammary tumor retrovirus in human breast cancer. Int J Cancer. 2013;133(7):1530-5. DOI: 10.1002/ijc.28210 PMID: 23580334

5. Salmons B, Lawson JS, Gunzburg WH. Recent developments linking retroviruses to human breast cancer: infectious agent, enemy within or both? J Gen Virol. 2014;95(Pt 12):2589-93. DOI: 10.1099/vir.0.070631-0 PMID: 25217613

6. Buehring GC, Shen HM, Jensen HM, Choi KY, Sun D, Nuovo G. Bovine leukemia virus DNA in human breast tissue. Emerg Infect Dis. 2014;20(5):772-82. DOI: 10.3201/ eid2005.131298 PMID: 24750974

7. Buehring GC, Shen HM, Jensen HM, Jin DL, Hudes M, 
Block G. Exposure to Bovine Leukemia Virus Is Associated with Breast Cancer: A Case-Control Study. PLoS One. 2015;10(9):e0134304. DOI: 10.1371/journal. pone.0134304 PMID: 26332838

8. Corredor AP, Gonzalez J, Baquero LA, Curtidor H, OlayaGalan NN, Patarroyo MA, et al. In silico and in vitro analysis of boAP3d1 protein interaction with bovine leukaemia virus gp51. PLoS One. 2018;13(6):e0199397. DOI: 10.1371/journal.pone.0199397 PMID: 29928016

9. Trono KG, Perez-Filgueira DM, Duffy S, Borca MV, Carrillo C. Seroprevalence of bovine leukemia virus in dairy cattle in Argentina: comparison of sensitivity and specificity of different detection methods. Vet Microbiol. 2001;83(3):235-48. PMID: 11574172

10. Gillet N, Florins A, Boxus M, Burteau C, Nigro A, Vandermeers $\mathrm{F}$, et al. Mechanisms of leukemogenesis induced by bovine leukemia virus: prospects for novel anti-retroviral therapies in human. Retrovirology. 2007;4:18. DOI: 10.1186/1742-4690-4-18 PMID: 17362524

11. Kanno T, Ishihara R, Hatama S, Oue Y, Edamatsu H, Konno $\mathrm{Y}$, et al. Effect of freezing treatment on colostrum to prevent the transmission of bovine leukemia virus. J Vet Med Sci. 2014;76(2):255-7. PMID: 24067450

12. Buehring GC, Philpott SM, Choi KY. Humans have antibodies reactive with Bovine leukemia virus. AIDS Res Hum Retroviruses. 2003;19(12):1105-13. DOI: 10.1089/088922203771881202 PMID: 14709247

13. Giovanna M, Ulloa JC, Uribe AM, Gutierrez MF. Bovine leukemia virus gene segment detected in human breast tissue. Open J Med Microbiol. 2013;3(1):84.

14. Robinson LA, Jaing CJ, Pierce Campbell C, Magliocco A, Xiong Y, Magliocco G, et al. Molecular evidence of viral DNA in non-small cell lung cancer and non-neoplastic lung. Br J Cancer. 2016;115(4):497-504. DOI: 10.1038/ bjc.2016.213 PMID: 27415011

15. Stott ML, Thurmond MC, Dunn SJ, Osburn BI, Stott JL. Integrated bovine leukosis proviral DNA in T helper and T cytotoxic/suppressor lymphocytes. J Gen Virol. 1991;72 ( Pt 2):307-15. DOI: 10.1099/0022-1317-72-2-307 PMID: $\underline{1847172}$

16. Buehring GC, Kramme PM, Schultz RD. Evidence for bovine leukemia virus in mammary epithelial cells of infected cows. Lab Invest. 1994;71(3):359-65. PMID: 7933986

17. Rodriguez SM, Florins A, Gillet N, de Brogniez A, Sanchez-Alcaraz MT, Boxus M, et al. Preventive and therapeutic strategies for bovine leukemia virus: lessons for HTLV. Viruses. 2011;3(7):1210-48. DOI: 10.3390/v3071210 PMID: 21994777

18. Lairmore MD. Animal models of bovine leukemia virus and human T-lymphotrophic virus type-1: insights in transmission and pathogenesis. Annu Rev Anim Biosci. 2014;2:189-208. DOI: 10.1146/annurev-animal-022513-114117 PMID: 25384140

19. Jacobs RM, Messick JB, Valli VE. Tumors of the Hemolymphatic System. In: Meuten DJ, editor. Tumors in Domestic Animals. 4th ed: John Wiley \& Sons; 2008. p. 119-99.

20. Kobayashi S, Hidano A, Tsutsui T, Yamamoto T, Hayama $\mathrm{Y}$, Nishida T, et al. Analysis of risk factors associated with bovine leukemia virus seropositivity within dairy and beef breeding farms in Japan: a nationwide survey. Res Vet Sci. 2014;96(1):47-53. DOI: 10.1016/j.rvsc.2013.11.014 PMID: 24370261

21. Bauermann FV, Ridpath JF, Dargatz DA. Bovine leukemia virus seroprevalence among cattle presented for slaughter in the United States. J Vet Diagn Invest. 2017;29(5):704-6. DOI: $10.1177 / 1040638717702183$ PMID: 28381128

22. Xu A, van Eijk MJ, Park C, Lewin HA. Polymorphism in BoLA-DRB3 exon 2 correlates with resistance to persistent lymphocytosis caused by bovine leukemia virus. J Immunol. 1993;151(12):6977-85. PMID: 8258704

23. Niermann GL, Buehring GC. Hormone regulation of bovine leukemia virus via the long terminal repeat. Virology. 1997;239(2):249-58. DOI: 10.1006/viro.1997.8868 PMID: $\underline{9434716}$

24. Xiao J, Buehring GC. In vivo protein binding and functional analysis of cis-acting elements in the $\mathrm{U} 3$ region of the bovine leukemia virus long terminal repeat. J Virol. 1998;72(7):5994-6003. PMID: 9621062

25. Reyes RA, Cockerell GL. Unintegrated bovine leukemia virus DNA: association with viral expression and disease. J Virol. 1996;70(8):4961-5. PMID: 8764001

26. Murakami H, Yamada T, Suzuki M, Nakahara Y, Suzuki K, Sentsui H. Bovine leukemia virus integration site selection in cattle that develop leukemia. Virus Res. 2011;156(12):107-12. DOI: 10.1016/j.virusres.2011.01.004 PMID: $\underline{21237224}$

27. Szynal M, Cleuter Y, Beskorwayne T, Bagnis C, Van Lint C, Kerkhofs P, et al. Disruption of B-cell homeostatic control mediated by the BLV-Tax oncoprotein: association with the upregulation of Bcl-2 and signaling through NFкB. Oncogene. 2003;22(29):4531.

28. Philpott SM, Buehring GC. Defective DNA repair in cells with human T-cell leukemia/bovine leukemia viruses: role of tax gene. J Natl Cancer Inst. 1999;91(11):933-42. PMID: 10359545

29. Gillet NA, Hamaidia M, de Brogniez A, Gutierrez G, Renotte N, Reichert M, et al. Bovine Leukemia Virus Small Noncoding RNAs Are Functional Elements That Regulate Replication and Contribute to Oncogenesis In Vivo. PLoS Pathog. 2016;12(4):e1005588. DOI: 10.1371/ journal.ppat.1005588 PMID: 27123579

30. Durkin K, Rosewick N, Artesi M, Hahaut V, Griebel P, Arsic $\mathrm{N}$, et al. Characterization of novel Bovine Leukemia Virus (BLV) antisense transcripts by deep sequencing reveals constitutive expression in tumors and transcriptional interaction with viral microRNAs. Retrovirology. 2016;13(1):33. DOI: 10.1186/s12977-016-0267-8 PMID: 27141823

31. Ochoa-Cruz A, Uribe A, Gutierrez M. Zoonotic Behavior of the Bovine Leukemia Virus and Its Relationship with Breast Cancer. Univ Sci. 2006;11(2):31-40.

32. Gardner SN, Jaing CJ, McLoughlin KS, Slezak TR. A microbial detection array (MDA) for viral and bacterial detection. BMC Genomics. 2010;11:668. DOI: 10.1186/14712164-11-668 PMID: 21108826

33. Buehring GC, Shen H, Schwartz DA, Lawson JS. Bovine leukemia virus linked to breast cancer in Australian 
women and identified before breast cancer development. PLoS One. 2017;12(6):e0179367. DOI: 10.1371/journal. pone.0179367 PMID: 28640828

34. Panal Cusati M, Herrera de la Muela M, Hardisson Hernaez D, Choqueneira Dionisio M, Román Guindo A, de Santiago Garcia FJ. [Correlation between Ki67 expression with classic prognostic and predictive factors in early breast cancer]. Rev Senol Patol Mamaria. 2014;27(4):1639. DOI:10.1016/j.senol.2014.07.005

35. Olaya-Galan NN, Corredor-Figueroa AP, Guzman-Garzon TC, Rios-Hernandez KS, Salas-Cardenas SP, Patarroyo MA, et al. Bovine leukaemia virus DNA in fresh milk and raw beef for human consumption. Epidemiol Infect. 2017;145(15):3125-30. DOI: 10.1017/ S0950268817002229 PMID: 28956522

36. Barrios C, Rensetti D, Revelli G, Ceriani C, Trabattoni E, Esteban EN, et al. Bovine leukemia virus infect more than $99 \%$ of dairy farms with endemic diseases in beef herds during 2012, north of parallel $34^{\circ} \mathrm{S}$. Argentina 2012.

37. Giraudo J, Bérgamo E, Schneider E, Magnano G, Macias A, Sticotti E, et al. Bovine Enzootic Leukosis Argentina:
Sitio Argentino de Producción Animal; 2010 [cited 2018 November 26]. Available from: http://www.produccion-animal.com.ar/.

38. Acaite J, Tamosiunas V, Lukauskas K, Milius J, Pieskus J. The eradication experience of enzootic bovine leukosis from Lithuania. Prev Vet Med. 2007;82(1-2):83-9. DOI: 10.1016/j.prevetmed.2007.05.010 PMID: 17640751

39. Nuotio L, Rusanen H, Sihvonen L, Neuvonen E. Eradication of enzootic bovine leukosis from Finland. Prev Vet Med. 2003;59(1-2):43-9. PMID: 12719016

40. Hayes D, Burton L. Enzootic bovine leucosis eradication scheme. Surveillance. 1998;25(4):3-5.

41. Gutiérrez G, Rodríguez SM, Vilor A, Gillet N, DeBrogniez A, Trono K, et al. An efficient vaccine against bovine leukemia virus. Retrovirology. 2015;12(Suppl 1):P3-P. DOI: 10.1186/1742-4690-12-S1-P3 PMID: PMC4578280

42. Martinez Cuesta L, Lendez PA, Nieto Farias MV, Dolcini GL, Ceriani MC. Can Bovine Leukemia Virus Be Related to Human Breast Cancer? A Review of the Evidence. J Mammary Gland Biol Neoplasia. 2018;23(3):101-7. DOI: $\underline{10.1007 / \mathrm{s} 10911-018-9397-\mathrm{Z}}$ 